\title{
Design, Fabrication and Performance Test of Axial Flow Hydro Turbine
}

\author{
Nandar Win ${ }^{1}$, Myat Myat Soe ${ }^{2}$, Aung Myat Thu ${ }^{3} \&$ War War Min Swe \\ Research Scholar ${ }^{1}$, Professor $^{2-3}$, Associate Professor ${ }^{4}$ \\ ${ }^{1-4}$ Department of Mechanical Engineering \\ Mandalay Technological University, Myanmar \\ Patheingyi, Mandalay
}

The Republic of the Union Myanmar

\begin{abstract}
Hydropower is the source of renewable energy for more than a century leading to a decrease in the burning of fossil fuels which has an effect on the environment. The axial flow hydro turbine is placed for a small water flow rate and the low head application. Axial flow hydro turbine consists of guide vane mounted in the stationary casing and blades connected on the hub. Axial flow hydro turbine consists of four runner blades, the number of guide vane is 6 and the guide vane angle is $73^{\circ}$. In this research, the available head and flow rate are $3.4 \mathrm{~m}$ and $0.14 \mathrm{~m} 3 / \mathrm{sec}$. Hydrofoil shape of runner blade selected NACA 6412 and modeling the blade geometry used SolidWorks software. In this research, the modal of the axial flow hydro turbine is made with thermoplastic filament material due to produce easily. The turbine assembly was tested with various water velocities at Lon Town Irrigation Channel in Madayar Township, Myanmar. Experimental results of turbine shaft power and generator output power are also estimated in this research. The maximum turbine shaft power and generator output power are observed $3.66 \mathrm{~kW}$ and $3 \mathrm{~kW}$ at volume flow rate of $0.15 \mathrm{~m} 3 / \mathrm{s}$.
\end{abstract}

Key Words: NACA 6412, Axial Flow Turbine, Water Velocities, Shaft Power, Generator Output Power.

\section{INTRODUCTION}

The request for growing the use of renewable energy has increased over the previous few years due to environmental issues. The great emissions of greenhouse gases have headed to serious deviations in the climate. The field of renewable energy contains, for example wind, solar and hydro power. Hydropower was the first renewable source which was used to generate electricity over 100 years ago. Today, hydropower is an important source of producing electrical energy [1]. A hydraulic turbine is a rotating engine that extracts energy from fluid flow and converts it into useful work. It converts the potential energy into electricity through a generator. In axial flow turbine, water flow through the sequences of blade rows and blade profile is considered at different sections from hub to casing to get the best performance. An axial flow turbine where the energy transformation occurs over the guide vane attached in the stationary casing, and the rotating blades attached on the hub .This grouping of wicket gates and blades creates blade cascade [2].

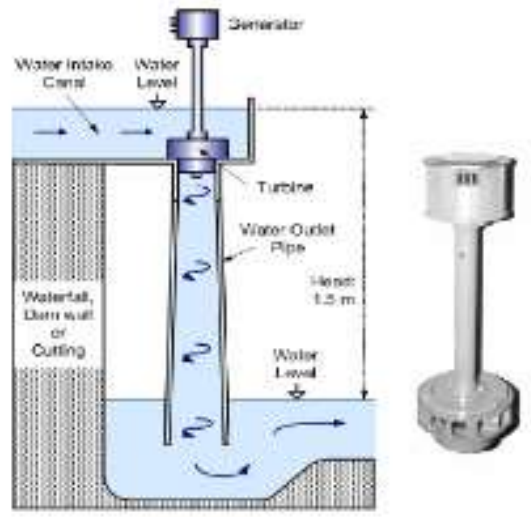


Figure 1. Layout of Axial Flow Hydro Power Plant [4]

Axial flow hydro turbine is the best appropriate turbine in low head case. In axial flow turbine, water flow through the sequences of blade and changes its flow direction from radial to axial. Runner is the main component of the turbine and its blade profile is considered at different sections from hub to tip which is achieved the best efficiency [5].

The selected hydro power is a basic reaction hydro turbine well appropriate for low water head and low water flow rate. In addition, the turbine does not put a gear box for coupling to the generator. Fig. 1 shows the general layout of implement of axial flow hydro turbine.

In the research, an effort has been made to modelling of low head axial flow turbine and to study its performance. The tested hydraulic turbine is $3 \mathrm{~kW}$ model designed for average $3.4 \mathrm{~m}$ head and a maximum water flow rate of $0.14 \mathrm{~m}^{3} / \mathrm{s}$.

\section{METHODOLOGY}

In this research, design of axial flow turbine runner is presented and performed to test the turbine in irrigation channel. The runner of axial flow turbine is the main part of a reaction turbine in the power generation. The runner normally has three to six blades of hydrofoil shape as the number of blades depends on the specific speed. The runner blades are attached and cannot change their position.

The blades are multifaceted to manufacture due to their asymmetrical shape, and the design is based on airfoil profiles, due to the blades capacity to generate a big lift force and a relatively low drag force.

In this study, turbine output power is considered $3 \mathrm{~kW}$ and head of turbine is assumed $3.4 \mathrm{~m}$. Generator speed and efficiency is $1500 \mathrm{rpm}$ and 0.8 respectively. Runner blade is divided into five different parts from hub to tip. Fig 2 shows five different section of runner blade.
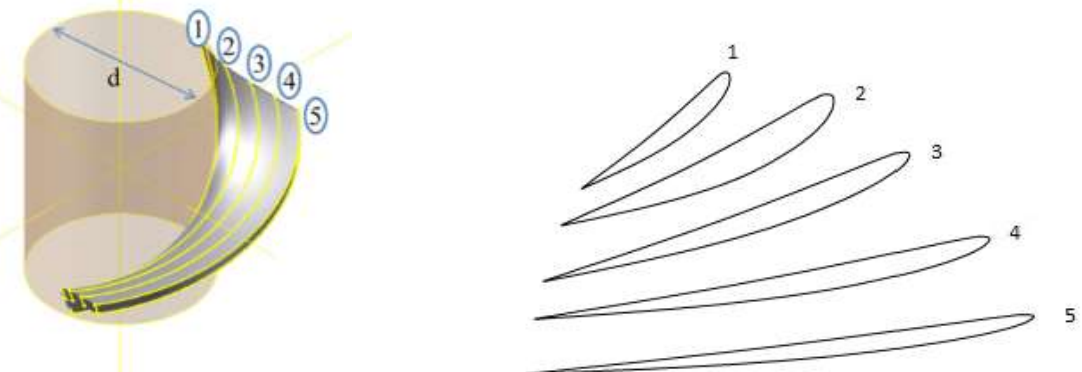

Figure 2. Five Sections for Runner Blade [6]

\subsection{Runner Blade Design}

The required shaft power established by a turbine is designed by following formula;

$$
P_{s}=\frac{P_{e}}{\eta_{g}}
$$

Turbine speed is calculated using the following design parameters: effective head $\mathrm{H}$ and rotational specific speed.

$$
\mathrm{N}_{\mathrm{s}}=\frac{885.5}{\mathrm{H}^{0.25}}
$$

Turbine speed, $\mathrm{N}=\frac{\mathrm{N}_{\mathrm{s}} \mathrm{H}^{1.25}}{\sqrt{\mathrm{P}_{\mathrm{s}}}}$

Speed factor, $\quad \varphi=0.0242\left(\mathrm{~N}_{\mathrm{S}}\right)^{2 / 3}$

Runner diameter,

$$
\mathrm{D}=\frac{84.5 \times \varphi \times \sqrt{\mathrm{H}}}{\mathrm{N}}
$$

Support on specific speed, values of flow coefficient, speed coefficient and hub to tip diameter ratio (d/D) are selected.

Number of blade, $z=4$

$\mathrm{d} / \mathrm{D}=0.415$ 
Then, flow velocity factor is calculated by using equation,

Flow area, $A=\pi / 4\left(D^{2}-d^{2}\right)$

Flow rate, $\mathrm{Q}=\mathrm{A} \times \mathrm{V}_{\mathrm{f}}$

The power established by a turbine is calculated by following formula.

$\mathrm{P}_{\mathrm{s}}=\rho \mathrm{g} \mathrm{Q} \mathrm{H} \eta_{\mathrm{o}}$

Assume, at outlet whirl velocity, $\mathrm{V}_{\mathrm{w} 2}=0$

$\because$ Absolute velocity, $\mathrm{V}_{2}$ is axial flow.

i.e.; $\alpha_{2}=90^{\circ}$

Then, radius of blade profile $r_{1}, r_{2}, r_{3}, r_{4}$ and $r_{5}$ are computed and tangential velocity $(U)$, blade inlet angle $\left(\beta_{1}\right)$, blade outlet angle $\left(\beta_{2}\right)$, blade spacing $\left(\mathrm{t}_{\mathrm{s}}\right)$, whirl velocity $\left(\mathrm{V}_{\mathrm{w}}\right)$, circulation $(\Gamma)$, angle of attack $(\alpha)$ and blade angle $(\beta)$ for five different sections are also calculated.

\subsection{Guide Vane Design}

The purpose of guide blade is to support the water to the runner at a certain velocity and flow direction. The following formula may be used to calculate the number of guide vane,

$$
\mathrm{z}_{1}=\frac{1}{4} \sqrt{\mathrm{D}^{\prime}}+4 \text { to } 6
$$

Then, guide vane inlet angle $\left(\alpha_{1}\right)$, length of guide vane $(\mathrm{L})$, height of guide vane $(\mathrm{H})$ can be designed by the following equation. Fig. 3 shows the modeling of guide design.

$$
\begin{aligned}
& \text { Guide vane inlet angle, } \alpha_{1}=\tan ^{-1} \frac{\mathrm{V}_{\mathrm{f}}}{\mathrm{V}_{\mathrm{w} 1}} \\
& \text { Length of guide vane, } \mathrm{L}=\frac{1.5 \mathrm{D} / 2-\mathrm{D} / 2}{\sin \alpha_{1}}
\end{aligned}
$$

Height of guide vane, $\frac{\mathrm{B}}{\mathrm{D}}=0.42 \quad[11]$

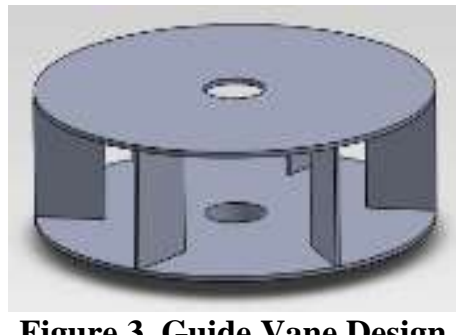

\subsection{Casing Design}

There are many different type of casing. They are open-flume, steel cylinder case, scroll or spiral casing, concrete scroll case. Among these casing spiral type is considered the best type. To keep the water velocity constant through its part around the runner, the cross-sectional area of the casing is gradually decreased. Spiral case can be provided at lower heads as well and it would give a more efficient arrangement [6].

Spiral casing can be designed by the followings. These dimensions are related to the runner discharge diameter. Fig. 4 shows the diagram of casing design. 


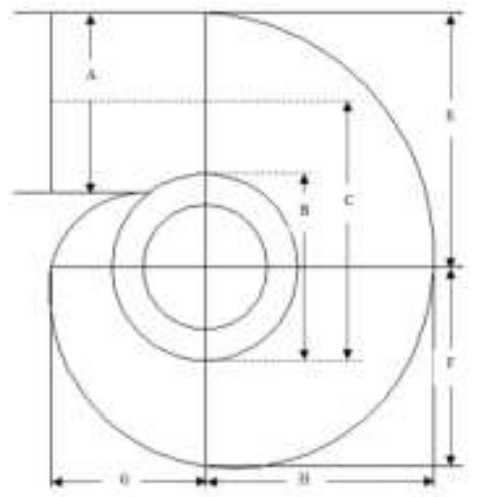

$$
\begin{aligned}
& A=1.45 D \\
& B=1.5 D \\
& C=1.9 D \\
& E=2.05 D \\
& F=1.6 D \\
& G=1.25 D
\end{aligned}
$$

\subsection{Draft Tube Design}

Figure 4. Casing Design [7]

The draft tube is a cylinder tube of steadily increasing area which attaches the outlet of the runner to the tail race. It is used for release water from the outlet of the turbine to the tail race. One end of the draft tube is linked to the outlet of the runner while the other end is flooded below the level of water in the tail race. Because of the draft tube, it is possible to have the pressure at runner outlet much below the atmospheric pressure [8]. Fig. 5 shows the draft tube design. The results data of runner blade profile for five different sections are explained in Table 1.

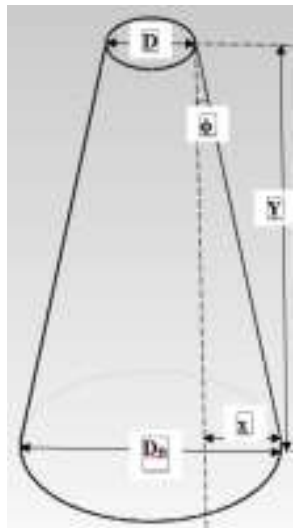

$$
\begin{aligned}
& \mathrm{Y}=10 \mathrm{D} \\
& \mathrm{x}=\mathrm{Y} \tan \phi \\
& \mathrm{D}_{\mathrm{ft}}=\mathrm{D}+2 \mathrm{x}
\end{aligned}
$$

Figure 5. Draft Tube Design

Table 1: Result data of blade profile for five sections

\begin{tabular}{|c|c|c|c|c|c|}
\hline Parameter & I & II & III & IV & V \\
\hline $\mathrm{r}_{1}(\mathrm{~m})$ & 0.036 & 0.0505 & 0.065 & 0.074 & 0.083 \\
\hline $\mathrm{U}_{1}(\mathrm{~m} / \mathrm{s})$ & 5.862 & 8.223 & 10.59 & 12 & 13.43 \\
\hline $\mathrm{V}_{\mathrm{f}}(\mathrm{m} / \mathrm{s})$ & 7.455 & 7.455 & 7.455 & 7.455 & 7.455 \\
\hline$\beta_{1}($ degree $)$ & 86 & 59.39 & 44.36 & 38.44 & 33.9 \\
\hline$\beta_{2}($ degree $)$ & 52 & 42.19 & 35.16 & 31.84 & 29.04 \\
\hline $\mathrm{V}_{\mathrm{w} 1}(\mathrm{~m} / \mathrm{s})$ & 5.348 & 3.81 & 2.962 & 2.61 & 2.34 \\
\hline $\mathrm{W}_{\alpha 1}(\mathrm{~m} / \mathrm{s})$ & 3.188 & 6.317 & 9.103 & 10.69 & 12.26 \\
\hline$\beta_{\alpha}(\mathrm{degree})$ & 67 & 49.72 & 39.31 & 34.86 & 31.31 \\
\hline $\mathrm{W}_{\alpha}(\mathrm{m} / \mathrm{s})$ & 8.108 & 9.77 & 11.766 & 13.04 & 14.35 \\
\hline $\mathrm{t}_{\mathrm{s}}(\mathrm{m})$ & 0.057 & 0.079 & 0.102 & 0.12 & 0.13 \\
\hline$\Gamma(\mathrm{m} 2 / \mathrm{s})$ & 0.3 & 0.3 & 0.3 & 0.3 & 0.3 \\
\hline $1 / \mathrm{t}_{\mathrm{s}}$ & 1.1 & 1.0125 & 0.925 & 0.84 & 0.74 \\
\hline $1(\mathrm{~m})$ & 0.06 & 0.08 & 0.094 & 0.097 & 0.096 \\
\hline$\alpha($ degree $)$ & 12.57 & 4.85 & 2.54 & 1.18 & 0.61 \\
\hline$\beta($ degree $)$ & 35.57 & 45.276 & 53.23 & 56.3 & 59.3 \\
\hline
\end{tabular}




\section{PERFORMANCE TEST OF AXIAL FLOW HYDRO TURBINE}

In this research, design of axial flow hydro turbine and performance test are presented. Axial flow hydro turbine can operate under low head conditions and that material and build capacity for local fabrication is available. Axial flow hydro turbines can attain high rotational speeds without a transmission system. The turbine produced approximately $3 \mathrm{~kW}$ of shaft power when the rotational speed has been obtained about $1500 \mathrm{rpm}$.

\subsection{Fabrication Process}

Fused Deposition Modeling (FDM) is an additive manufacturing technology commonly used for modeling, prototyping, and production applications. A thermoplastic filament material supplies to an extrusion nozzle. The nozzle is heated to melt the material and can be motivated in both horizontal and vertical directions by a numerically controlled mechanism, directly controlled by a computer-aided manufacturing (CAM) software package. Fig. 6 shows fabrication process of runner (using thermoplastic material).
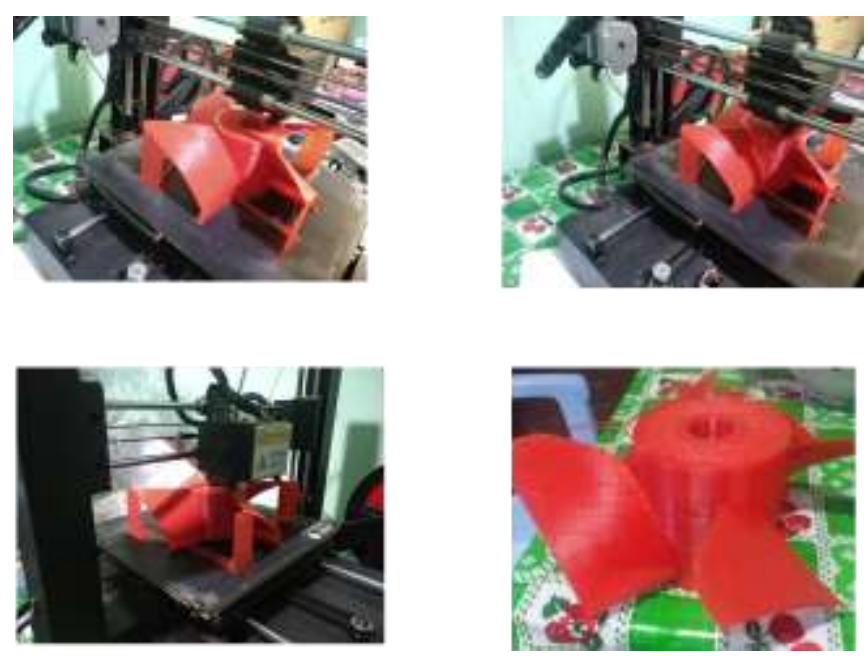

Figure 6. Fabrication Process of Runner

\subsection{Installation Process}
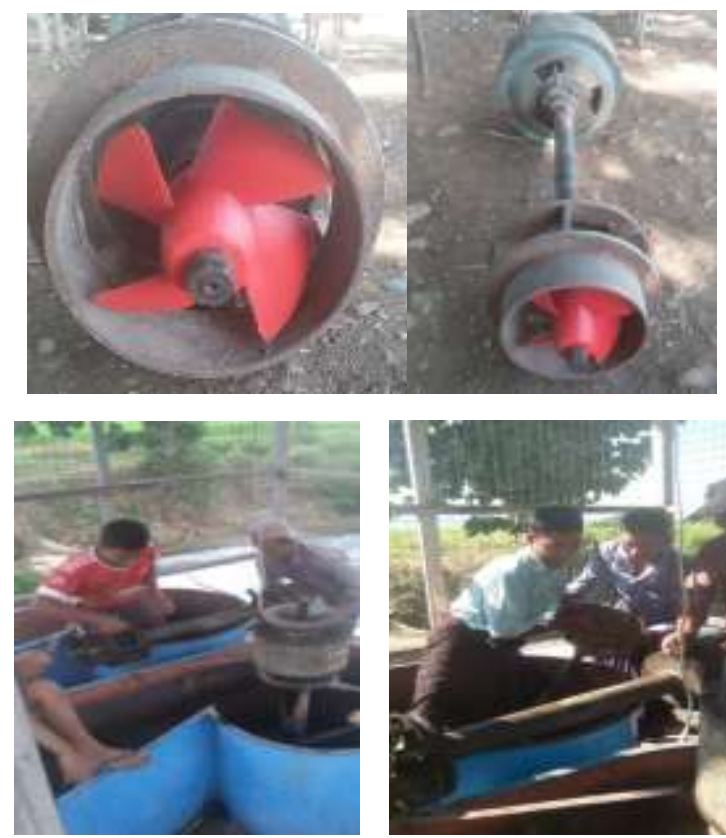

Figure 7. Installation Process of Turbine

The turbine assembly was tested at Lon Town Irrigation Channel at Madayar Township. Firstly, turbine runner is manufactured by 3D printer with thermoplastic material. The runner replaced from old runner of axial flow hydro turbine and it is directly mounted to the shaft. Transmission gear is not required in this system. After that, turbine runner attached with guide vane of axial flow hydro turbine. Finally, it is connected to the generator to produce electrical power. Fig. 7 shows installation process of turbine to performance test. 


\subsection{Measuring Instruments and Methods}

There are some instruments which are used to measure the water flow velocity, turbine speed, voltage and current of the generator. Flow meter which is placed above water level and the value of flow velocity can be read the LCD display. Clamp meter is used to measure the current and voltage. The wire is put into the clamp meter and the result data can be read the display. The speed of shaft can be measured by Tachometer.

\subsection{Site Location}

It is well known that the best performance and the highest power production of the axial flow hydro turbine is made by a smooth linear flow of water at high velocity. The flow characteristic of a stream has a stochastic variation, both seasonal and daily. Additionally the water velocity varies from one potential site to the other depend the cross-sectional area; therefore, this location must be very well considered for experimental test. Fig. 8 shows Lon Town Irrigation Channel at Madayar Township.
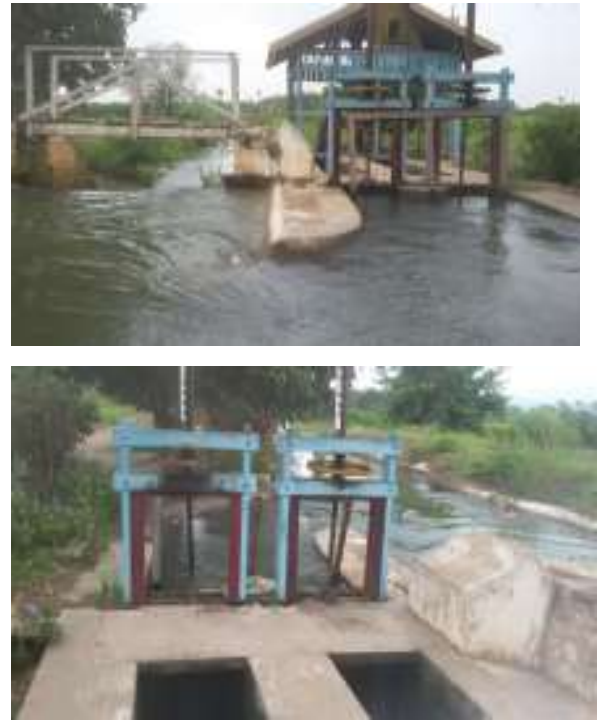
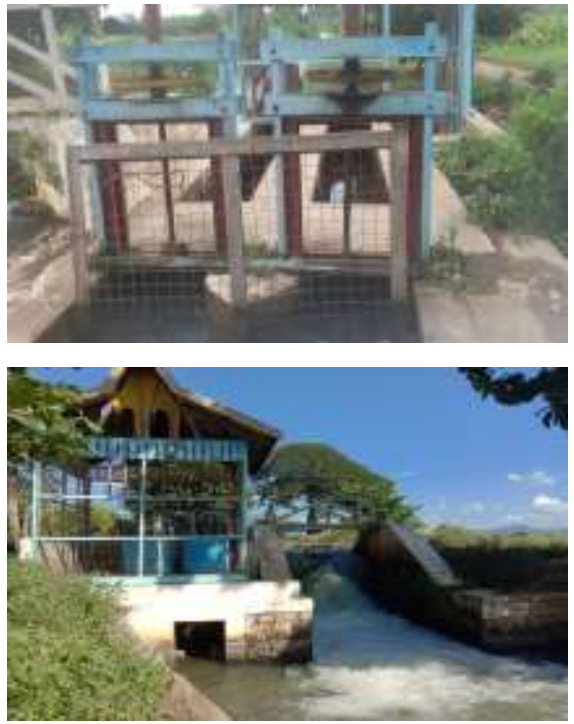

Figure 8. Lon Town Irrigation Channel at Madayar Township

\subsection{Performance Test Procedure}

Assembly of axial flow hydro turbine placed and operated in the spiral casing of hydro power plant. Firstly, water flows from main irrigation to channel for turbine operate controlled by gate which is placed at the top of the channel. The water in the channel flows to get water velocity operating condition of turbine. Fig. 9 shows performance test procedure step by step at selected location. Water velocity passes through the rotating machinery then exit to the water outlet through the draft tube. The different value of water velocity under control the gate tested the operating turbine. The torque and speed of the operating turbine data are collected from running condition of turbine by using tachometer. The collected data is used to estimate shaft power and generator output power. 
International Journal of Advances in Scientific Research and Engineering (ijasre), Vol 5 (12), December-2019
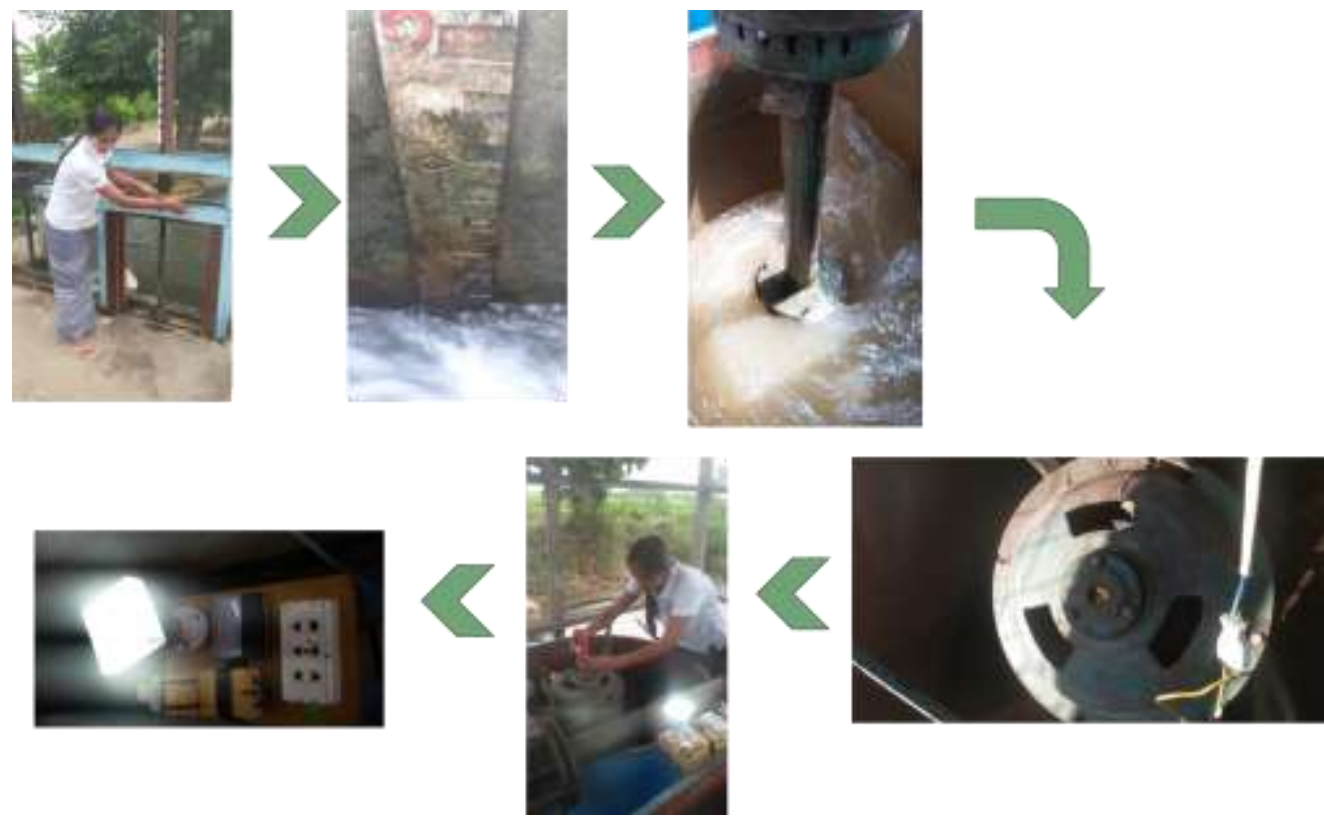

Figure 9. Performance Test Procedure

\subsection{Performance Test Results and Discussion}

Performance test on the constructed turbine were conducted at Lon Town Irrigation Channel, Madayar Township. The experiments are carried out on the axial flow turbine to find out the performance at water velocity. From the measurements and calculation that have been done in the experiment as presented for result data of runner at various water velocity.

Table 2. Experimental Results Data for $1^{\text {st }}$ Time

\begin{tabular}{|c|c|c|c|c|c|c|c|}
\hline Run & $\begin{array}{c}\text { Flow } \\
\text { Rate, Q } \\
\left(\mathrm{m}^{3} / \mathrm{s}\right)\end{array}$ & $\begin{array}{c}\text { Water } \\
\text { Velocity, } \\
\mathrm{V}_{\mathrm{w}}(\mathrm{m} / \mathrm{s})\end{array}$ & $\begin{array}{c}\text { Turbine } \\
\text { Speed, N } \\
(\mathrm{rpm})\end{array}$ & $\begin{array}{c}\text { Angular } \\
\text { Velocity, } \omega \\
(\mathrm{rad} / \mathrm{s})\end{array}$ & $\begin{array}{c}\text { Torque, T } \\
(\mathrm{N}-\mathrm{m})\end{array}$ & $\begin{array}{c}\text { Shaft Power, } \\
\mathrm{P}_{\mathrm{s}}(\mathrm{kW})\end{array}$ & $\begin{array}{c}\text { Generator } \\
\text { Output Power, } \\
\text { Pg }(\mathrm{kW})\end{array}$ \\
\hline 1 & 0.084 & 0.4 & 931 & 98 & 7.8 & 0.77 & 0.61 \\
\hline 2 & 0.095 & 0.5 & 1056 & 110 & 10 & 1.1 & 0.89 \\
\hline 3 & 0.102 & 0.6 & 1132 & 119 & 11.6 & 1.4 & 1.1 \\
\hline 4 & 0.105 & 0.7 & 1163 & 122 & 12.2 & 1.5 & 1.2 \\
\hline 5 & 0.113 & 0.9 & 1250 & 131 & 14.1 & 1.85 & 1.5 \\
\hline 6 & 0.128 & 1.4 & 1415 & 148 & 18 & 2.7 & 2.2 \\
\hline 7 & 0.14 & 1.6 & 1515 & 159 & 20.1 & 3.1 & 2.4 \\
\hline
\end{tabular}

Table 3. Experimental Results Data for $2^{\text {nd }}$ Time

\begin{tabular}{|c|c|c|c|c|c|c|c|c|}
\hline Run & $\begin{array}{c}\text { Water } \\
\text { Depth(m) }\end{array}$ & $\begin{array}{c}\text { Flow } \\
\text { Rate, Q } \\
\left(\mathrm{m}^{3} / \mathrm{s}\right)\end{array}$ & $\begin{array}{c}\text { Water } \\
\text { Velocity, } \\
\mathrm{V}(\mathrm{m} / \mathrm{s})\end{array}$ & $\begin{array}{c}\text { Turbine } \\
\text { Speed, } \\
(\mathrm{rpm})\end{array}$ & $\begin{array}{c}\text { Angular } \\
\text { Velocity, } \omega \\
(\mathrm{rad} / \mathrm{s})\end{array}$ & $\begin{array}{c}\text { Torque, T } \\
(\mathrm{N}-\mathrm{m})\end{array}$ & $\begin{array}{c}\text { Shaft Power, } \\
\mathrm{P}(\mathrm{kW})\end{array}$ & $\begin{array}{c}\text { Generator } \\
\text { Output Power, } \\
\mathrm{Pg}(\mathrm{kW})\end{array}$ \\
\hline 1 & 0.122 & 0.086 & 0.6 & 952 & 100 & 8.2 & 0.82 & 0.65 \\
\hline 2 & 0.183 & 0.092 & 0.64 & 1022 & 107 & 9.4 & 1.01 & 1.45 \\
\hline 3 & 0.186 & 0.103 & 0.8 & 1153 & 121 & 125 & 1.16 \\
\hline 4 & 0.305 & 0.107 & 0.86 & 1190 & 125 & 12.8 & 1.6 & 1.28 \\
\hline 5 & 0.366 & 0.109 & 0.9 & 1216 & 127 & 13 & 1.7 & 1.3 \\
\hline 6 & 0.457 & 0.124 & 0.92 & 1374 & 144 & 17 & 2.5 & 2 \\
\hline
\end{tabular}


International Journal of Advances in Scientific Research and Engineering (ijasre), Vol 5 (12), December-2019

\begin{tabular}{|l|l|l|l|l|l|l|l|l|}
\hline 7 & 0.488 & 0.15 & 1.72 & 1599 & 163 & 22.5 & 3.66 & 3.0 \\
\hline
\end{tabular}

The generator output power is observed the product of generator efficiency and shaft power. The results data of generator output power are expressed in Table 2 and 3. From the measurements and calculation that have been done in the experiment as presented in the above Tables. The maximum generator output power is $3 \mathrm{~kW}$ occur at water velocity $1.72 \mathrm{~m} / \mathrm{s}$.

Experimental data for various shaft power of turbine that carried out in the experimental test with various mass flow rates are plotted in the graphs. Performance analysis of shaft power and power output from generator are shown in the following Fig. 10, 11 and 12 .
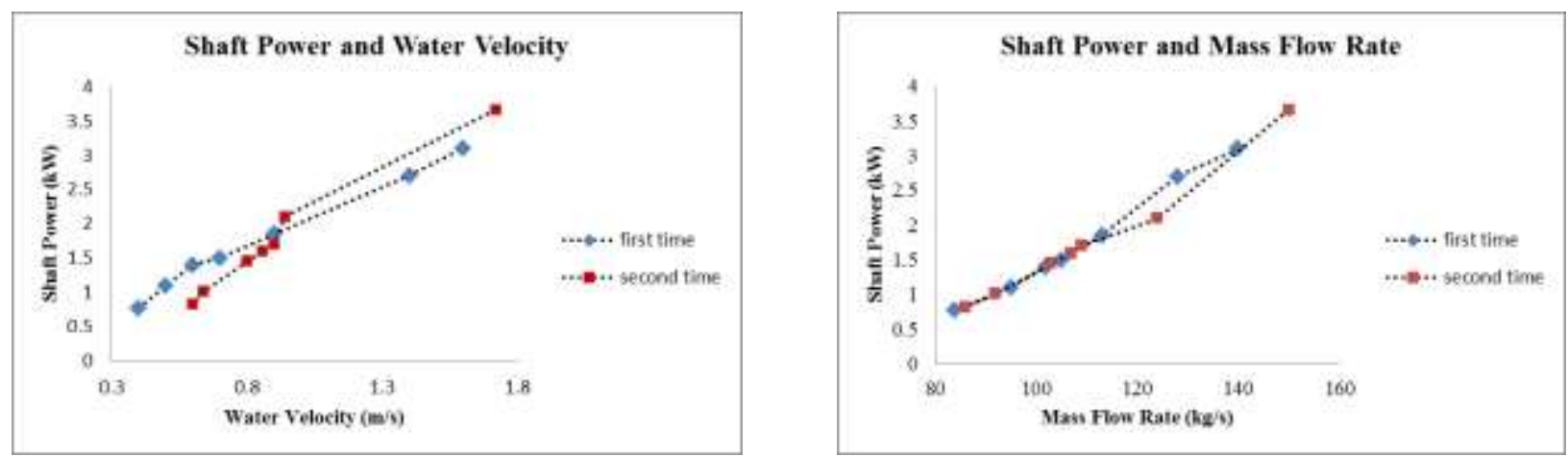

Figure 10. Performance Results of Shaft Power

In the $1^{\text {st }}$ performance test, volume flow rate is changed by control valve and water velocity is measured. The turbine is tested with various of water velocities $0.4 \mathrm{~m} / \mathrm{s}$ to $1.6 \mathrm{~m} / \mathrm{s}$. Following that, turbine speed $(\mathrm{N})$ is measured by Tachometer. The amount of mass flow rate into the turbine is estimated by using the value of turbine speed. Fig.10 shows performance results data of shaft power. Turbine shaft power is calculated from the value of rotational speed. It has been found that turbine shaft power increases with inecrease in the mass flow rate. Generator output power or required power of this research is estimated from shaft power with multiply generator efficiency of turbine. Generator efficiency is assumed, while consideration of design calculation of axial flow hydro turbine. Maximum shaft power and generator output power are $3.1 \mathrm{~kW}$ and $2.4 \mathrm{~kW}$ respectively.
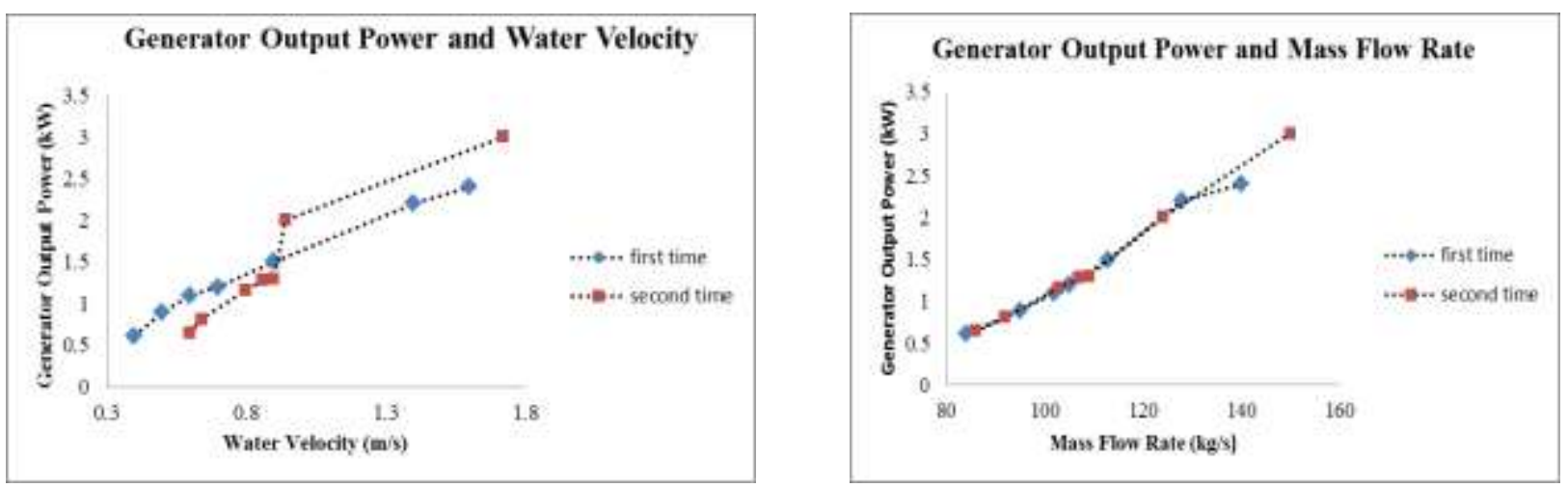

Figure 11. Performance Results of Generator Output Power

In the $2^{\text {nd }}$ performance test, the turbine is tested various of water velocites from $0.6 \mathrm{~m} / \mathrm{s}$ to $1.72 \mathrm{~m} / \mathrm{s}$ but performance results data are plotted with mass flow rates. Fig.11 shows performance results data of generator output power. It has been found that shaft power is $3.66 \mathrm{~kW}$ at mass flow rate $150 \mathrm{~kg} / \mathrm{s}$. Turbine speed is nearly $1600 \mathrm{rpm}$ at that mass flow rate. 

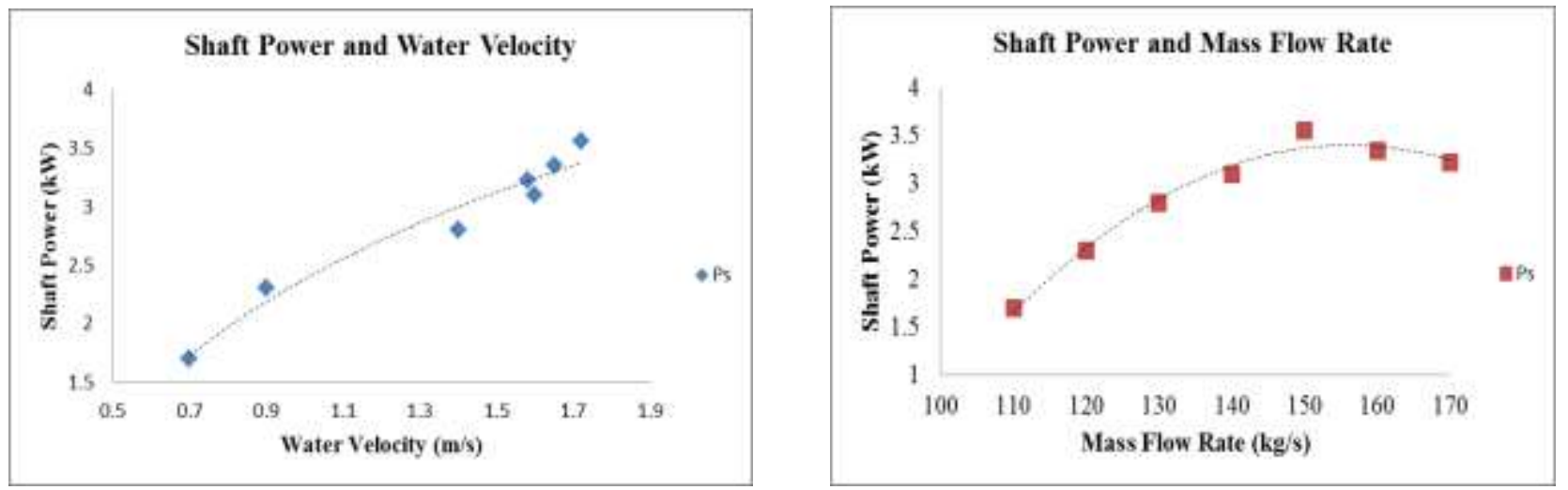

Figure 12. Shaft Power at Various Mass Flow Rates and Water Velocities

In this performance test, the turbine is tested with several of mass flow rate (from $110 \mathrm{~kg} / \mathrm{s}$ to $170 \mathrm{~kg} / \mathrm{s}$ ) as flow analysis is simulated with different mass flow rate. The amount of mass flow rate into the turbine is calculated from the performance result of turbine speed. Fig. 12 shows shaft power at various mass flow rates and water velocities. It can be seen that maximum shaft power is about $3.5 \mathrm{~kW}$ at $150 \mathrm{~kg} / \mathrm{s}$. Following that, shaft power is gradually decreased to $3 \mathrm{~kW}$.

\section{CONCLUSION}

In this research study on the performance analysis of axial flow hydro turbine has been carried out using 3D printed runner blade. Performance test on the constructed turbine were conducted at Lon Town Irrigation Channel, Madayar Township. The experiments are carried out on the axial flow turbine to find out the performance at various water velocities. From the performance results data, maximum turbine speed occur at mass flow rate $150 \mathrm{~kg} / \mathrm{s}$. Hence, rotating shaft power is $3.66 \mathrm{~kW}$ at turbine speed about $1600 \mathrm{rpm}$. Generator output power or required power of this research is estimated by using shaft power. So, maximum generator power out is $3 \mathrm{~kW}$.

\section{ACKNOWLEDGMENTS}

The First of all, the author wishes to express her deep gratitude to Dr. Ei Ei Htwe, Pro-Rector, Mandalay Technology University, for her kindness and valuable permission to summit the paper for the research. A special thanks is offered to Dr. Win Pa Pa Myo, Professor and Head of Department of Mechanical Engineering, Mandalay Technological University, for her encouragement, constructive guidance and kindly advice throughout the preparation of this research. The author especially would like to take this opportunity to express her sincere gratitude, respect and regards to supervisor Dr. Myat Myat Soe, Professor, Department of Mechanical Engineering, Mandalay Technological University, under whose guidance, constant encouragement, patient and trust on this research.

\section{NOMENCLATURE}

$\begin{array}{ccc}\text { Symbol } & \text { Description } & \text { Unit } \\ \mathrm{P}_{\mathrm{s}} & \text { shaft power } & \mathrm{kW} \\ \mathrm{P}_{\mathrm{e}} & \text { electrical power } & \mathrm{kW} \\ \mathrm{N}_{\mathrm{s}} & \text { generator speed } & \mathrm{rpm} \\ \mathrm{H} & \text { head of turbine } & \mathrm{m} \\ \mathrm{D} & \text { runner diameter } & \mathrm{m} \\ \mathrm{d} & \text { hub diameter } & \mathrm{m} \\ \mathrm{z} & \text { number of blade } & - \\ \mathrm{r}_{1-5} & \text { radius of blade profile } & \mathrm{m} \\ \mathrm{U}_{1} & \text { tangential velocity } & \mathrm{m} / \mathrm{s} \\ \beta_{1} & \text { blade inlet angle } & \text { degree } \\ \beta_{2} & \text { blade outlet angle } & \text { degree } \\ \mathrm{V}_{\mathrm{w} 1} & \text { whirl velocity } & \text { degree } \\ \mathrm{t}_{\mathrm{s}} & \text { blade spacing } & \mathrm{m} \\ 1 & \text { chord length } & \mathrm{m} \\ \mathrm{W}_{\alpha} & \text { average relative velocity } & \text { degree } \\ \Gamma & \text { circulation } & \mathrm{m} / \mathrm{s} \\ \phi & \text { draft tube angle } & \text { degree } \\ \mathrm{D}_{\mathrm{ft}} & \text { draft tube diameter } & \mathrm{m}\end{array}$




\section{REFERENCES}

1. Roberto Agromayor and Lars O. Nord, "Preliminary Design and Optimization of Axial Turbines Accounting for Diffuser Performance", Department of Energy and Process Engineering, NTNU-The Norwegian University of Science and Technology, Norway, September, 2019.

2. S.Abdolkarim Payambarpour, Amir F. Najafi, FrancoMagnagnato, "Investigation of Blade Number Effect on Hydraulic Performance of In-Pipe Hydro Survonius Turbine", Institute of Fluid Mechanics, Karlsruhe Institute of Technology, Germany, 2019.

3. Shri Krishna Gupta, Anshu Prakash Maurya, Ankit kumar Maurya and Priyanka Jhavar, Design and Flow Analysis of Enhanced Kaplan Turbine, International Journal of Advanced Research in Science and Engineering, vol. 6, issue 1, December 2017.

4. Dinesh Kumar, Saurabh Sangal and R.P.Saini, Flow Analysis of Kaplan Hydraulic Turbine by Computational Fluid Dynamics, Research Gate, June.2013.

5. B. Ho-Yan, Design of a Low Head Pico Hydro Turbine for Rural Electrification in Cameroon, University of Guelph, 2012.

6. Dr. S.K. Dave, Ashokkumar A. Parmar, Ankit P. Shah and Nikhil M. Vyas, Pico Hydro Power Generation: Renewable Energy Technology for Rural Electrification, International Journal of Advanced Science in Engineering, Science and Management.

7. Vishnu Prasad,B, "CFD Approach for Design Optimization and Validation for Axial Flow Hydraulic Turbine", Inidian Journal of Engineering and Materials Sciences, Volume 16, August 2009.

8. Vineet Kumar Singh, Neha Singh Chauhan and Deepti Kushwaha, "An Overview of Hydro-Electric Power Plant", ISST Journal of Mechanical Engineering, Vol. 6, no. 1, pp. 59-62, January - June, 2015.

9. Yohannis Mitiku Tobo, A.Venkata Ramayya, Getachew Shunki Tibba, “CFD Simulation and Optimization of Very Low Head Axial Turbine runner", IJRED, ISSN: 2252-4940, October 15, 2015.

10. M.Nakisa, A.Maimun, Yasser M.Ahmed, “Computational Fluid Dynamic (CFD) Mesh Inedpendency Technique for a Propeller Characteristics in Open Water Condition", Jurnal Teknologi, May, 2015.

11. Nitin Kolekar, Zhe Hu, Arindam Banerjee, and Xiaoping Du, Hydrodynamic Design and Optimizing of Hydro-Kinetic Turbine Using Robust Design Method, in proceeding of the $1^{\text {st }}$ Marine Energy Technology Symposium, Washington, D.C., 2013.

12. Kumar, D.S.: "Fluid Mechanics and Fluid Power Engineering", 6th Ed., Punjab Engineering College, 1998.

13. Barrows H.K.: "Water Power Engineering”, 3rd Ed., McGraw Hill, New York, 1943.

14. Miroslav Nechleba, "HYDRAULIC TURBINES: Their Design and Equipment”, ARTIA Prague, Czechoslovakia, 1957. 